\title{
Shielding Failure
}

National Cancer Institute

\section{Source}

National Cancer Institute. Shielding Failure. NCI Thesaurus. Code C62842.

Problem associated with the device inability to act as a barrier for absorption of radiation energy in X-rays, gamma rays, etc. 